\title{
Pengaruh Penerapan E-Voting Terhadap Tingkat Partisipasi Politik Masyarakat Pada Pemilihan Waliagari Batu Taba Kabupaten Agam Tahun 2019
}

\author{
Rizki Novaldi ${ }^{1}$, dan M. Fachri Adnan ${ }^{2}$ \\ ${ }^{1}$ Mahasiswa Jurusan Ilmu Administrasi Negara, Universitas Negeri Padang \\ ${ }^{2}$ Dosen Jurusan Ilmu Administrasi Negara, Universitas Negeri Padang \\ Email Author: ${ }^{1}$ rizkinovaldi33@gmail.com, ${ }^{2}$ fachriadnan@fis.unp.ac.id
}

\begin{abstract}
This research is motivated by the level of community participation in Nagari Batu Taba where there are still many levels of public apathy about politics, especially in general elections. In 2019, Nagari Batu Taba held a general election using e-voting which previously was still conventional (based on ballot paper). The purpose of the study was to analyze regardless of the effect of the application of e-voting on the level of community political participation in the Election of Walinagari Batu Taba, Agam Regency in 2019. The method used in this study is a quantitative method. Respondents in this study are people who are registered in the Permanent Voters List who use their voting rights in walinagari elections and are taken using the Simple Random Sampling technique. The results showed that the e-voting variable had a significant effect on conventional (paper-based) community political participation, which had an Adjust R Square value of 0.706 or $71 \%$ and the remaining $29 \%$ was based on other variables not examined in this study. In this case, the application of e-voting has a significant effect on the level of community political participation in the 2019 Election of Walinagari Batu Taba, Agam Regency.
\end{abstract}

Keywords: E-Voting, Political Participation, Walinagari Election.

\section{PENDAHULUAN}

Di negara demokrasi, pemilihan pemimpin dan wakilnya dipilih oleh rakyatnya dengan cara voting. Voting yang dimaksud ialah seseorang memilih pilihannya dengan mencoblos pilihannya dalam proses pemilihan melalui media kertas. Dalam pelaksanaan voting secara konvensional atau menggunakan kertas suara masih memiliki banyak kekurangan dalam peaksanaannya seperti masih tingginya resiko kesalahan dalam penghitungan suara dan masih rawannya kecurangan pada jumlah suara untuk kebutuhan partai dan atau golongan tertentu (Drehem, Djanali, \& Pratomo, 2016).

Kecurangan banyak terjadi pada proses kegiatan voting, kecurangan ini sering terjadi ketika dalam proses penghitungan suara dimana banyak pihak partai atau golongan tertentu melakukan kecurangan terhadap jumlah suara. Akibat seringnya terjadi masalah tersebut dalam pelaksanaan voting secara konvensional ini membuat masyarakat menjadi kurang percaya terhadap hasil suara (Anistiawati, 2014).

Seiring berkembang teknologi informasi, pemerintah memanfaatkan perkembangan teknologi informasi dengan berharap dapat menjadi jawaban untuk tuntutan terselenggara pemerintah yang baik serta dapat terjadinya pemerataan dalam memberikan pelayanan. Hal ini menjadi alasan bagi pemerintah untuk mengambil teknologi tersebut sebagai langkah supaya dapat menjadi perbaikan infrastruktur dalam pelayanan publik. Penggunaan teknologi informasi oleh pemerintah untuk masyarakat saat ini biasanya dikenal dengan nama $E$ Government.

Pelaksanaan voting sekarang bisa dilaksanakan menggunakan elektronik atau menggunakan teknologi informasi yang dikenal dengan elektronic voting (e-voting). Dengan adanya $e$-voting dapat mengurangi permasalahan yang ada ketika pelaksanaan pemilihan secara konvensional (berbasis kertas suara). Selain itu, $e$-voting juga dapat 
Jurnal Ilmu Sosial dan Pendidikan

http://ejournal.mandalanursa.org/index.php/JISIP/index

Terakreditasi Peringkat 5 (No. SK: 85/M/KPT/2020)

mengurangi pengeluaran biaya (cost) pada proses pelaksanaan pemilihan umum. Dalam penerapan $e$-voting, surat suara tidak lagi digunakan oleh seluruh pemilih. Langkah yang dipakai dalam proses e-voting adalah menetukan pilihan dengan cara menyentuh layar (touch screen) atau mengklik pada layar elektronik yang telah disediakan (Anistiawati, 2014).

E-Voting atau Electronic voting adalah proses pemilihan umum yang mengambil manfaat dari perangkat elektronik, di mana seluruh atau sebagian proses kegiatannya, dimulai dari pendaftaran pemilih, pemungutan suara, sampai penghitungan suara, dilaksanakan secara elektronik. Tujuan pemakaian $e$-voting bukan hanya untuk mempercepat proses kegiatan pemilihan umum saja, namun ada juga menjaga orisinalitas dari suara pemilih, kerahasiaan pemilih, dan juga menjaga keakuratan penghitungan suara (Drehem, Djanali, \& Pratomo, 2016). Terdapat beberapa aspek atau indikator yang dapat mempengaruhi berjalannya dengan baik sebuah sistem pada $e$-voting (Shalahuddin, 2009), yakni : (1) Teknologi, (2) Hukum, (3) Sosial, dan (4) Prosedur Operasional.

Terdapat beberapa kelebihan electronic voting (e-voting) ini dari pada dengan cara konvensional (berbasis kertas) antara lain dari segi waktu menjadi lebih cepat ketika proses memilih dan penghitungan hasil pemilihan, kemudian akurat, tepat dan cepat diketahui sehingga untuk mengetahui hasilnya tidak butuh waktu lama. Sama halnya dalam hal biaya menjadi lebih hemat daripada menggunakan dengan manual dimana mencetak surat suara terlebih dahulu dan terkadang surat suara tersebut tidak digunakan semuanya, serta pemakaian $e$ voting ini lebih jelas, trasnparan dan tidak akan ada suara yang tidak sah (Nisa \& Adnan, 2019).

Di Indonesia sendiri kegiatan pemilu secara $e$-voting sudah dilakukan pada tahun 2009. Adapun kabupaten yang pertama di Indonesia yang sudah mempraktekkan sistem $e$-voting adalah di Kabupaten Jembrana, Bali pada pemilihan kepala dusun (Pilkadus).
Vol. 5. No. 1 Januari 2021

p-ISSN: 2598-9944 e- ISSN: 2656-6753

Pemilihan secara $e$-voting ini juga telah dilaksanakan pada Maret 2013 di Kabupaten Boyolali Jawa Tengah pada pemilihan kepala desa (Pilkades), dan pada Pilkades di Kabupaten Bantaeng pada April 2013, dan pada September 2016 di Kabupaten Pemalang, Jawa Tengah pada pilkades (Firmansyah, 2018).

Dalam riset yang dilakukan oleh penulis terdapat beberapa riset yang sama sebelumnya terkait dengan pengaruh penerapan $e$-voting terhadap partisipasi politik masyarakat. Riset pertama adalah pada penelitian Fajara Nugraha, Cecep Darmawan, dan Sunatra (2014) dimana hasil dari penelitiannya adalah menyebutkan terdapat korelasi yang cukup kuat dalam menerapkan metode e-voting terhadap partisipasi politik pada pemilihan Ketua OSIS SMAN 1 Manonjaya, bukti kalau penggunaan $e$-voting berpengaruh kepada partisipasi politik yakni tingkat partisipasi politik siswa menjadi lebih tinggi dibandingkan ketika memakai cara lama atau berbasis kertas. Kemudian Chika Nisa Amanda dan Sri Wibawani (2019) juga meneliti hal yang sama, hasil dari risetnya ialah pemilihan kepala desa dengan $e$-voting berpengaruh kepada partisipasi politik masyarakat di Desa Kepuhkiriman Kabupaten Sidoarjo.

Salah satu pelaksanaan $e$-voting saat sekarang ini adalah pada pemilihan walinagari Batu Taba Tahun 2019 di Kecamatan Ampek Angkek Kabupaten Agam. Pelaksanaan evoting ini merupakan pertama kali dilaksanakan dalam pemilihan walinagari di Nagari Batu Taba.

Namun dalam pelaksanaan e-voting pada pemilihan walinagari di Nagari Batu Taba, terdapat beberapa permasalahan. Adapun permasalahan tersebut berdasarkan hasil wawancara dari Pak Mulyadi sebagai Sekretaris Nagari, beliau mengatakan terdapat beberapa masalah yang dihadapi seperti kurangnya fasilitas atau sarana dan prasarana seperti alat $e$-voting yang terbatas dikarenakan biaya yang dikeluarkan sangat besar untuk membeli alat tersebut. Hal ini mengakibatkan beberapa orang menunda pemberian suara dengan alasan mereka mempunyai 
Jurnal IImu Sosial dan Pendidikan

http://ejournal.mandalanursa.org/index.php/JISIP/index

Terakreditasi Peringkat 5 (No. SK: 85/M/KPT/2020)

urusan/kepentingan yang harus dikerjakan. Sehigga kebanyakan dari mereka yang telah menunda tersebut menjadi malas untuk kembali mengikuti pemilihan walingari ini.

Kemudian kurangnya sosialisasi kepada masyarakat tentang pelaksanaan dan bagaimana penggunaan e-voting. Dan masalah yang sama dengan pelaksanaan pemilihan sebelumnya yakni kurangnya kesadaran masyarakat untuk berpartisipasi dalam menggunakan hak pilihnya pada pemiihan walinagari tersebut. Padahal dengan adanya sistem baru dalam pelaksanaan pemilu ini diharapkan dapat meningkatkan partisipasi masyarakat dengan adanya rasa ingin tahu masyarakat akan kegunaan $e$-voting terhadap pemilu. Padahal Qadah dan Taha dalam (Azizah, 2018) menyebutkan tujuan dari penerapan $e$-voting ini adalah meningkatkan partisipasi masyarakat pada pemilu, menekan biaya dan meningkatkan validitas dan akurasi pemilu. Rallings dan Transher dalam jurnal yang sama (Azizah, 2018) mengatakan bahwa dengan adanya penekanan biaya dalam $e$ voting dapat meningkatkan partisipasi masyarakat.

Begitu sebaliknya, praktek demokrasi akan terlihat buruk pada suatu negara apabila tingkat partisipasi politik masyarakat mereka rendah. Hal-hal tersebut ditandai dengan masyarakat yang sama sekali atau kurang peduli terhadap masalah pemilu dan masalah lainnya yang berhubungan dengan negaranya. Terdapat indikator partisipasi politik pemilih dalam pemilihan umum (Kusmanto, 2013), yakni mengikuti diskusi politik, ikut berkampanye, serta menggunakan/memakai hak suara.

Padahal Grofmen, Owen dan Collet (Bochsler, 2010) mengatakan dampak besar dari internet atau electronic voting pada tingkat partisipasi pemilih tergantung pada fungsi yang menghubungkan antara pemilih dengan jumlah suara dan tingkat paritispasi dari kelompok sosial. Pemungutan suara secara elektronik atau digital dapat memberikan fasilitas dalam proses pemungutan suara bagi orang yang sudah mengetahui dengan baik tentang politik dan mengetahui orang yang berkemungkinan
Vol. 5. No. 1 Januari 2021

p-ISSN: 2598-9944 e- ISSN: 2656-6753

besar untuk ikut berpartisipasi dalam pemilu. Memang, pendidikan dan pendapatan yang tinggi menjadi dua dari tiga faktor yang berkorelasi paling kuat dengan partisipasi politik di Amerika Utara, Eropa Barat, dan di negara-negara anggota UE yang baru (Bochsler, 2010).

Setelah mengetahui permasalahan diatas, penulis dapat menjelaskan tingkat partispasi masyarakat di Nagari Batu Taba masih belum tinggi yang dapat diihat dari penjelasan diatas, maka dari itu, perlu ditingkatkan lagi partisipasi masyarakat. Berhubungan dengan permasalahan diatas maka peneliti memiliki ide untuk mengambil dan melakukan penelitian dengan judul "Pengaruh Penerapan E-Voting terhadap Tingkat Partisipasi Politik Masyarakat pada Pemilihan Walinagari Batu Taba Kabupaten Agam Tahun 2019". Penelitian ini memiliki tujuan untuk mengetahui serta menganalisa seberapa besar pengaruh penerapan $e$-voting terhadap tingkat partsipasi politik masyarakat pada Pemilihan Walinagari Batu Taba Kabupaten Agam Tahun 2019.

\section{METODE PENELITIAN}

Peneliti pada artikel penelitian ini memakai metode kuantitatif. Adapun lokasi dipakai peneliti yakni di Nagari Batu Taba Kabupaten Agam. Adapun populasi yang diambil disini adalah masyarakat yang ikut serta pada pemilihan walinagari, menggunakan pilihnya serta menggunakan sistem e-voting tersebut. Teknik yang digunakan peneliti dalam menentukan responden adalah teknik Simple Random Sampling $_{\text {i yakni secara acak mengambil }}$ beberapah responden tanpah memperhatikan strata pada masyarakat Nagari Batu Taba dengan jumlah 90 orang. Adapun jumlah orang telah ditetapkan tersebut merupakan orang yang ikut serta pada pemilihan walinagari, menggunakan pilihnya serta menggunakan sistem $e$-voting tersebut.

Pada artikel penelitian ini, teknik pengumpulan data yang peneliti pakai ialah menggunakani cara memberikan angket ke responden dengan jumlah responden yang telah ditetapkan sebelumnya dengan 
menggunakan skala Likert. Data yang diperoleh, dikumpulkani kemudian dianalsis memakai uji regresi sederhana.

\section{HASIL DAN PEMBAHASAN}

A. Uji Asumsi Klasik

\section{Uji Normalitas}

Dalam uji ini dilaksanakan sebagai syarat guna menentukan analisis apa yang digunakan untuk menguji hipotesis, apabila berdistribusi normal maka analisis parametrik dilanjutkan.

\section{Gambar 1}

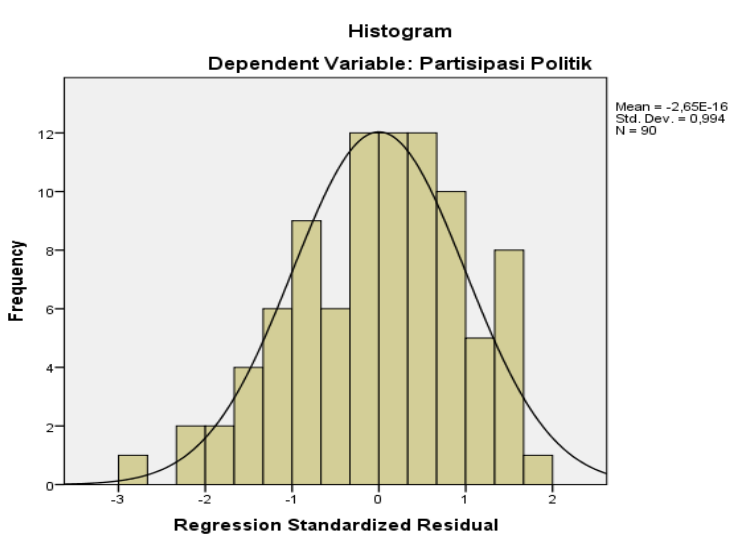

Sumber : Hasil Pengolahan Data 2020

Berdasarkan gambar 1 dapat diperoleh hasil data secara normalitas yang menunjukkan analisis data secara baik dan dapat dikatakan normal dilihat dari data penelitian ini terdistrusi normal karena persebaran data membentuk kurva normal.

\section{Uji Linearitas}

Tujuan pada pengujian ini ialah untuk melihat apakah spesifikasi yang telah dipakai sudah betul atau belum.

\section{Gambar 2}

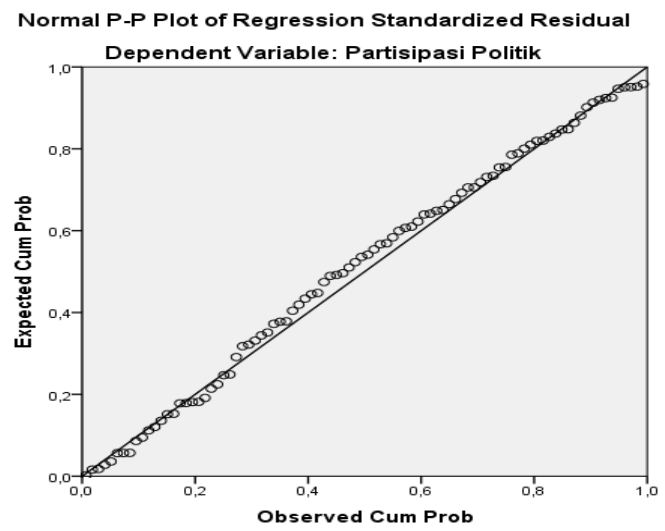

Sumber : Hasil Pengolahan Data 2020
Berdasarkan gambar 2 terlihat titiktitik bergerak serta menyebari dan mengikuti garis diagonal serta tidak terdapati penyebaran yang ekstrim. Yang berarti menunjukkan bentuk regresi ini sudah memenuhi syarat asumsi normal dari data yang ada sehingga dapat sesuai dengan asumsi klasik suatu regresi atau dapat menjadi hasil yangi baik.

\section{Uji Heteroskedastisitas}

Tujuan pengujian ini adalah guna mengetahui dan melihat apakah terjadi ketidaksamaan varians dari residual suatu pengamatan ke pengamatan lain pada model regresi ini.

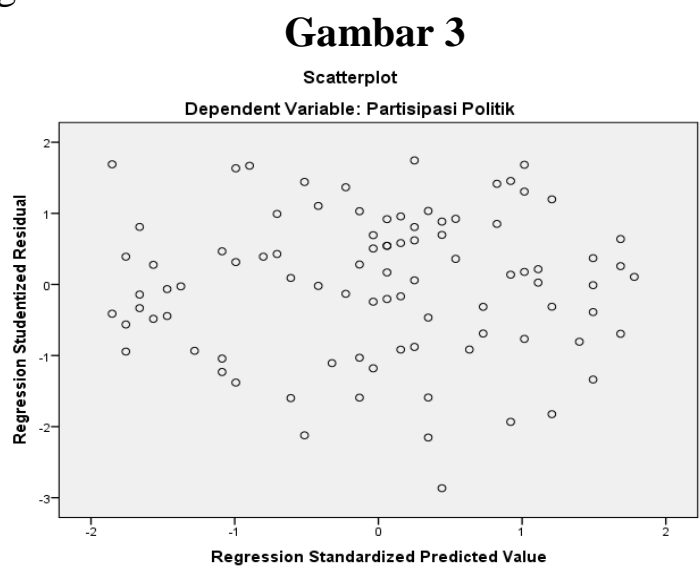

Sumber : Hasil Pengolahan Data 2020

Berdasarkan gambar 3 dapat dijelaskan hasil pengujian menunjukkan semua titik menyebar dengan acak dimulai dari bagian bawah angka noll sampai bagian atas angka noll pada dari sumbu vertikal $Y$ serta tidak membentuk pola tertentu. Jadi bisa diambil kesimpulan yakni tidak terdapat heterokedastisitas dan menunjukkan model regresi ini telah memenuhi syarat heterokedastisitas.

\section{Uji Multikolinearitas}

Tabel 1. Hasil Uji Multikoleniaritas Pengaruh Penerapan E-Voting Terhadap Partisipasi Politik

\begin{tabular}{|c|c|c|c|c|c|c|c|}
\hline \multirow{2}{*}{ Model } & \multicolumn{2}{|c|}{$\begin{array}{c}\text { Unstandardized } \\
\text { Coefficients }\end{array}$} & $\begin{array}{c}\text { Standardized } \\
\text { Coefficients }\end{array}$ & \multirow{2}{*}{$\mathrm{t}$} & \multirow{2}{*}{ Sig. } & \multicolumn{2}{|c|}{$\begin{array}{c}\text { Collinearity } \\
\text { Statistics }\end{array}$} \\
\cline { 2 - 6 } & $\mathrm{B}$ & Std. Error & Beta & & & Tolerance & VIF \\
\hline $\begin{array}{c}\text { (Consta } \\
\text { nt) }\end{array}$ & $-2,553$ & 2,799 & & $-0,912$ & 0,364 & & \\
\hline $\begin{array}{c}\text { E- } \\
\text { Voting }\end{array}$ & 0,797 & 0,054 & 0,842 & 14,646 & 0,000 & 1,000 & $\begin{array}{c}1,00 \\
0\end{array}$ \\
\hline \multicolumn{3}{|c|}{ a. Dependent Variable: Partisipasi Politik } \\
\multicolumn{3}{|c|}{ Sumber : Hasil Pengolahan Data 2020 }
\end{tabular}

Sumber : Hasil Pengolahan Data 2020 
Jurnal Ilmu Sosial dan Pendidikan

http://ejournal.mandalanursa.org/index.php/JISIP/index

Terakreditasi Peringkat 5 (No. SK: 85/M/KPT/2020)

Pada pengujian ini bertujuan untuk melihat apakah terdapat hubungan linier yang kuat antara masing-masing variabel independent terhadap variabel dependen.

Berdasarkan hasil olah data penelitian ini menunjukkan nilaii VIF (Variation Inflation Factor) variabel E-Voting (X) adalah 1,000 dengan nilai toleransi 1,000 . Hal ini menunjukkan tidak terdapat variabel yang mempunyaii nilai VIF yang lebih dari 10, dan juga nilai toleransi kurang dari 0,1. Maka dapat diambil kesimpulan variabel iindependent bebas dari masalah multikolinieritas.

\section{Uji Autokorelasi}

Tujuan pada pengujian ini ialah melihat apakah dalam persamaan regresi penelitian ini terdapat masalah autokorelasi atau tidak.

Tabel 2. Hasil Uji Autokorelasi Pengaruh Penerapan E-Voting Terhadap Partisipasi Politik

\begin{tabular}{|c|c|c|c|c|c|}
\hline \multicolumn{7}{|c|}{ Model Summary $^{\mathbf{b}}$} \\
\hline Model & $\mathrm{R}$ & $\begin{array}{c}\mathrm{R} \\
\text { Square }\end{array}$ & $\begin{array}{c}\text { Adjusted } \\
\mathrm{R} \\
\text { Square }\end{array}$ & $\begin{array}{c}\text { Std. } \\
\text { Error of } \\
\text { the } \\
\text { Estimate }\end{array}$ & $\begin{array}{c}\text { Durbin- } \\
\text { Watson }\end{array}$ \\
\hline 1 &, $842^{\mathrm{a}}$ & 0,709 & 0,706 & 5,369 & 1,685 \\
\hline \multicolumn{7}{|l}{ a. Predictors: (Constant), E-Voting } \\
\hline \multicolumn{5}{|l}{ b. Dependent Variable: Partisipasi Politik } \\
\hline
\end{tabular}

Sumber : Hasil Pengolahan Data 2020

Berdasarkan hasil pengolahan data yang diteliti, terdapat nilai Durbin Watson sebesar 1,685. Dari tabel diatas dapat diketahui $\mathrm{dL}=1,634, \mathrm{dU}=1,679$, dan $\mathrm{DW}$ (Durbin-Watson) sebesar 1,685. Kriterianya adalah jika hasil dari nilai dU $<$ DW $<$ (4 dU), maka tidak terdapat autokorelasi. Dan pada hasil uji penelitian ini adalah:

$$
\begin{aligned}
& \mathrm{dU}<\mathrm{DW}<(4-\mathrm{dU}) \\
& 1,679<1,685<2,231
\end{aligned}
$$$$
\text { Jadi dapat disimpulkan uji }
$$
autokorelasi pada penelitan ini adalah tidak terjadi autokorelasi.
B. Uji Regresi Linear Sederhana
1. Uji Hipotesis

Vol. 5. No. 1 Januari 2021

p-ISSN: 2598-9944 e-ISSN: 2656-6753

Tabel 3. Hasil Uji t Pengaruh Penerapan

\begin{tabular}{|c|c|c|c|c|c|c|}
\hline \multicolumn{7}{|c|}{ Coefficients $^{\circledR}$} \\
\hline & & \multicolumn{2}{|c|}{$\begin{array}{c}\text { Unstandardized } \\
\text { Coefficients }\end{array}$} & \multirow{2}{*}{\begin{tabular}{|c|}
$\begin{array}{c}\text { Standardized } \\
\text { Coefficients }\end{array}$ \\
Beta \\
\end{tabular}} & \multirow[b]{2}{*}{$\mathrm{T}$} & \multirow[b]{2}{*}{ Sig. } \\
\hline \multicolumn{2}{|c|}{ Model } & B & Std. Error & & & \\
\hline \multirow[t]{2}{*}{1} & (Constant) & $-2,553$ & 2,799 & &, 912 &, 364 \\
\hline & E-Voting &, 797 &, 054 &, 842 & 14,646 &, 000 \\
\hline
\end{tabular}
E-Voting TerhadapPartisipasi Politik

Sumber : Hasil Pengolahan Data 2020

Dari hasil penelitian tabel 1 dapat diketahui nilai signifikansi pada hipotesis ini sebesar 0,000 lebih kecil dari 0,05. Hasil ini dapat diambil kesimpulan bahwa $e$-voting terhadap partisipasi politik masyarakat.

\section{Koefesien Determinasi}

Tabel 4. Hasil Uji Koefisien Determinasi Pengaruh Penerapan E-Voting Terhadap Partisipasi Politik

Sumber: Hasil Pengolahan Data 2020

Berdasarkan dari hasil penelitian pada tabel 2 dapat diketahui nilai Adjust $R$ Square sebesar 0,706. Hasil ini menunjukkan bahwa variabel $e$-voting memberikan pengaruh terhadap variabel partisipasi politik masyarakat sebesar $71 \%$ dan sisanya $29 \%$ dari variabel lain yang tidak diteliti yang mempengaruhinya dalam penelitian ini.

Pengaruh Penerapan E-Voting Terhadap Tingkat Partisipasi Politik Masyarakat Pada Pemilihan Walinagari Batu Taba Kabupaten Agam Tahun 2019

Berdasarkan pada temuan yang telah dipaparkan oleh peneliti tentang Pengaruh $E$ Voting terhadap Tingkat Partisipasi Politik Masyarakat pada Pemilihan Walinagari Batu Taba Tahun 2019. Setelah penelitian dilakukan dan telah disertai dengan analisis data, dapat dibuktikan dari analisis data yang telah dilakukan tersebut kalau variabel $e$ voting berpengaruh terhadap partisipasi politik masyarakat.

Selanjutnya, variabel e-voting berpengaruh secara signifikan terhadap partisiasi politik karena nilai Adjusted $R$ Square 0,706 atau sebesar $71 \%$ pada taraf signifikansi 0,000. Dan sisanya 29\% dari variabel lain yang tidak diteliti yang 
Jurnal IImu Sosial dan Pendidikan

http://ejournal.mandalanursa.org/index.php/JISIP/index

Terakreditasi Peringkat 5 (No. SK: 85/M/KPT/2020)

mempengaruhinya dalam penelitian ini. Hasil analisis ini membuktikan teori Qadah dan Taha dalam (Azizah, 2018) yang mengatakan tujuan dari penerapan e-voting adalah meningkatkan partisipasi politik masyarakat, mengurangi biaya dan meningkatkan validitas dan akurasi pemilu. Sehingga dapat dikatakan semakin besar kekuatan pengaruh $e$-voting maka semakin besar pula Partisipasi Politik Masyarakat pada Pemilihan Walinagari Batu Taba Tahun 2019. Adapun $71 \%$ ini terdiri dari beberapa indikator literasi politik seperti Sosialisasi, Teknologi, Hukum, dan Prosedur Operasional.

\section{Sosialisasi}

Nilai paling tinggi pada indikator Sosialisasi terdapat pada pernyataan "Sebelum pemilihan walinagari, sosialisasi penggunaan $e$-voting sangat penting bagi masyarakat" yang memiliki nilai mean sebesar 3,6 dengan nilai TCR sebesar 72\% dan berada pada kategori tinggi. Hasil ini menjelaskan bahwa sosialisasi merupakan salah satu hal yang penting untuk menerapkan $e$-voting demi meningkatkan partisipasi masyarakat di Nagari Batu Taba.

Hal ini dibuktikan dengan wawancara bersama sekretaris nagari bahwa mereka telah melakukan sosialisasi tentang penggunaan $e$-voting sebelum pelaksanaan pemilihan walinagari. Dan penulis mendapatkan informasi tambahan dari responden sembari mereka mengisi angket yang penulis berikan mengenai adanya sosialisasi ini mereka mengatakan bahwa ada mengikuti sosialisasi tersebut di mesjid ketika bulan ramadhan, namun beberapa dari responden menganggap sosialisasi yang mereka ikuti masih kurang efektif karena sosialisasi yang dilaksanakan secara tiba-tiba dan dilaksanakan pada malam hari di bulan ramadhan. Penyebab kurang efektifnya adalah mereka mengatakan bahwa malam hari adalah hari mereka beristirahat.

\section{Teknologi}

Nilai paling tinggi pada indikator nilai paling tinggi yakni pada indikator Teknologi dengan pernyataan "Sistem e-
Vol. 5. No. 1 Januari 2021

p-ISSN: 2598-9944 e-ISSN: 2656-6753

voting yang digunakan ini dalam pemilihan walinagari mudah dipahami" yang memiliki nilai mean sebesar 3,8 dengan nilai TCR sebesar $75 \%$ dan berada pada kategori tinggi. Hasil ini menjelaskan teknologi menjadi salah satu dari hal penting dalami menerapkan e-voting demi meningkatkan partisipasi masyarakat di Nagari Batu Taba.

Hal ini dibuktikan dengan adanya pendapat dari beberapa responden mereka mengatakan hal yang sama yaitu penggunaan e-voting ini sangat mudah dipahami karena walaupun mereka tidak mengikuti sosialisasi mereka langsung dapat memahami penggunaan sistem ini ketika mereka memilih di TPS.

\section{Hukum}

Nilai paling tinggi yakni pada indikator Kepatuhan Hukum dengan pernyataan "Bila pemilih tidak mematuhi peraturan penggunaan e-voting dalam pemilihan walinagari, panitia pemilihan walinagari memberi arahan agar mengikuti peraturan secara benar" yang memiliki nilai mean sebesar 3,9 dengan nilai TCR sebesar $77,3 \%$ dan berada pada kategori tinggi. Hasil ini menjelaskan bahwa sosialisasi merupakan salah satu hal yang penting untuk menerapkan e-voting demi meningkatkan partisipasi masyarakat di Nagari Batu Taba.

Hal ini dibuktikan dengan hasil pengakuan dari beberapa responden dimana terdapat salah satu anggota keluarga responden yang tidak mematuhi dan tidak mengerti dengan adanya e-voting ini namun pantia pemilihan langsung membimbingnya supaya dapat mengikuti arahan yang diberikan oleh panitia.

\section{Prosedur Operasional}

Nilai paling tinggi yakni pada indikator Prosedur Operasional dengan pernyataan "Tata cara pemilihan walinagari menggunakan e-voting mudah dipahami" yang memiliki nilai mean sebesar 3,6 dengan nilai TCR sebesar $71,6 \%$ dan berada pada kategori tinggi. Hasil ini menjelaskan bahwa prosedur operasional merupakan salah satu hal yang 
penting untuk menerapkan e-voting demi meningkatkan partisipasi masyarakat di Nagari Batu Taba.

Hal ini dibuktikan dengan adanya pengakuan dari beberapa responden, mereka mengatakan bahwa tata cara $e$ voting ini sangat mudah dipahami karena walaupun mereka tidak mengikuti sosialisasi mereka langsung dapat memahami penggunaan sistem ini ketika mereka memilih di TPS.

Dari temuan khusus yang telah ditemukan oleh peneliti dapat disimpulkan bahwa penerapan $e$-voting ini memberikan pengaruh terhadap tingkat partisipasi politik masyarakat melalui sosialisasi, penggunaan teknologi, aturan dan hukum yang berlaku, dan prosedur operasional pada sistem $e$ voting.

\section{KESIMPULAN}

Berdasarkan hasil penelitian yang telah dilaksanakan oleh peneliti mengatakan pelaksanaan pemilihan walinagari menggunakan sistem $e$-voting di Nagari Batu Taba dapat meningkatkan partisipasi politik masyarakat dibandingkan dengan pelaksanaan pemilihan secara konvesional (berbasis kertas).

Bukti dari hal ini dilakukan oleh peneliti dapat dilihat hasil penelitian yang menunjukkan bahwa variabel $e$-voting berpengaruh secara signifikan terhadap partisipasi politik masyarakat yang memiliki nilai Adjust $R$ Square sebesar 0,706 yang artinya pengaruh penerapan $e$-voting terhadap tingkat partisipasi politik masyarakat sebesar $71 \%$ dan sisanya $29 \%$ dari variabel lain yang tidak diteliti yang mempengaruhinya dalam penelitian ini. Pada perkara ini, penerapan $e$ voting mempunyai pengaruh yang signifikan terhadap tingkat partisipasi politik masyarakat pada Pemilihan Walinagari Batu Taba Kabupaten Agam Tahun 2019.

\section{DAFTAR PUSTAKA}

Anistiawati, M. L. (2014). Implementasi Kebijakan Penerapan Elektronik Voting (E-Voting) Dalam Pemilihan
Kepala Desa (Studi Kasus : Pemilihan Kepala Desa di Desa Mendoyo Dangin Tukad, Kecamatan Mendoyo Kabupaten Jembrana). Jurnal CITIZEN CHARTER, 1(2).

Azizah, A. H. (2018). Analisis Faktor Kepercayaan Terhadap Teknologi Pada Keiniginan Masyarakat Dalam Mengadopsi E-Voting. Jurnal Ilmiah Teknologi Informasi Terapan, Vol.4, No.2, 109-115.

Azizah, A. H. (2018). Analisis Faktor Kepercayaan Terhadap Teknologi Pada Keiniginan Masyarakat Dalam Mengadopsi E-Voting. Jurnal Ilmiah Teknologi Informasi Terapan, 4(2), 109-115.

Bochsler, D. (2010). Can Internet Voting Increase Political Participation. Remote Electronic, 1-24.

Drehem, I. M., Djanali, S., \& Pratomo, B. A. (2016). Implementasi Kontrol Integritas E-kiosk untuk Pengamanan Sistem Pemungutan Suara Secara Elektronik (E-Voting). Jurnal TEKNIK ITS, 5(1), A14-A18.

Firmansyah, B. (2018). Implementasi Kebijakan Elecktonic Voting (EVoting) Dalam Pemilihan Kepala Desa Di Kabupaten Pemalang Tahun 2016. Journal of Politic and Government Studies, 8(1), 41-50.

Kusmanto, H. (2013). Peran Badan Permusyawaratan Daerah dalam Meningkatkan Partisipasi Politik Masyarakat. Jurnal Ilmu Pemerintahan dan Sosial Politik, Vol.1, No.1, 39-47.

Nisa, K., \& Adnan, M. F. (2019). Implementasi Elektronik Voting (EVoitng) Dalam Pemilihan Wakinagari Di Nagari Salareh Kabupaten Agam Tahun 2017. Journal of Residu, Vol.3, No.16, 39-48.

Shalahuddin, M. (2009). Pembuatan Model EVoting Berbasis Web (Studi Kasus Pemilu Legislatif Dan Presiden Indonesia). Tesis Institut Teknologi Bandung. 